\title{
Analyzing Factors Affecting Vocational Education Development to Support Regional Potential
}

\author{
Agus Wiyono $^{1}$, Suryanto ${ }^{1}$, Dedy Rahman ${ }^{2}$ Prehanto $^{3}$ \\ ${ }^{1}$ Department of Civil Engineering, Faculty of Engineering, Surabaya State University \\ ${ }^{2}$ Department of Mechanical Engineering, Faculty of Engineering, Surabaya State University \\ ${ }^{3}$ Department of Information, Faculty of Engineering, Surabaya State University \\ aguswiyono@unesa.ac.id
}

Keywords: Vocational Education development, vocational senior high school, regional potential

Abstract: The demands of skilled human resources increase in the era of Asia Economic Community. Therefore, government shall significantly have increased the number of skilled workers until 2019 in order to meet the needs in various sectors, especially education that provides life skill competence according to reginonal potential. This study aimed to determine factors affecting vocational education development to support regional potential were found by using Delphi method. those factors found were distance (between resident and school), population, number of junior high school students, road network, public transportation, land price, disaster prone, natural resource production, society participation, government commitment (policymaking), human resources of school managers.

\section{INTRODUCTION}

According to data obtained from the Education Department in 2017, there were 2 units of public vocational schools, and 46 units of private vocational schools. Based on equal access to education, it showed unevenly in each region or sub-district. Hence, government s necessary to build vocational senior high schools especially in areas without any access to vocational education.

From preliminary survey at two Vocational senior high school, it was obtained that 2 units of public vocational senior high school were located in Kalianget District, and Batuan subdistrict. This location was selected because total population aged $16-18$ years was 46,635 people or $31.38 \%$ of 148,632 people in Sumenep remain in those two areas, whereas the remaining $68.62 \%$ or equivalent to 101,991 people were spreaded in other 25 districts. These numbers shows that comparing between total area and population, the vocational senior high school is inadequate.

\subsection{Research Question}

It is necessary to develop vocational education solutions by inventorying factors affecting the development of vocational education in order to support the potential of the region. Thus the formulation of the problem as follows: What factors affect the development of vocational education to support the potential areas in Sumenep?

\subsection{Scope and Limitations of the Study}

The scope of the research area in Sumenep Madura Regency, while the substance of this study only discusses the findings of factors that influence the development of vocational education in supporting the territory in Sumenep Regency. Vocational education here is vocational education at the middle level or Vocational High School.

\section{LITERATURE}

\subsection{Policy in Education Development}

Education is a very important, because in the era of knowledge-based economy, quality of education is possibly to elevate the nation in many ways, for examples in economy, health, prosperity, competitiveness and technology.

In the social context, the purpose and content of vocational education is linked to the growing needs of the Business World and the Industrial World. Vocational education plays an active role by determining the level and direction of community change in the field of vocational. Education with 
in the UK (Kerr, 2006), or BLK "21" Program in Germany (de Haan, 2006) as well as the generic EFS checklist (Schroter, 2010). However, it was unclear whether national evaluation studies or examples of best practice were universally applicable in other countries, as many anthropologists have pointed out (Owens, 2012). A broad work on class ethnography involving ethnographers to enter the "lesson" world through participant observation has not been fully employed in formal educational settings to address ESD.

How ESD practiced greatly differs in their socio-political priorities, as do democracies surrounding their educational institutions, as well as a number of other historical, socio-cultural, political, ecological and economic factors. Some types of ESD focusing on social and health justice are more appropriate in some circumstances, for example, issues related to reproductive health in developing countries; while more environmentaleffects of the problem are more appropriate to others, such as the problems concerned with the consequences of high levels of consumption in the more affluent West society The diversity of institutional arrangements was interpreted in the context of broader socio-cultural influences in which both formal and informal learning takes place (eg see recent work by anthropologists in the EE field (Zarger, 2010; Efird, 2011; Kopnina 2013; Anderson, 2012).

\subsection{Competence Education}

The term "competence" in the context of educational issues, is technological progress and globalization coupled with new challenges that must be mastered: enhancing individualization and developing social diversity, accompanied in parallel by expanding economic and cultural uniformity, availability of rapidly growing information, to cope with increasing complexity and uncertainty.

This term is used to describe "in the future the ability to modify and shape the futures of our societies through active participation in sustainable development". "Gestaltungs kompetenz" includes the following eight key competencies:

- competence in foresighted;

- competence in interdisciplinary work;

- competence in cosmopolitan perception, cross-cultural understanding and cooperation;

- participatory skills;

- competence in planning and implementation;

- capacity for empathy, compassion and solidarity; included the National Foundation for Research (NFER) by implementing "citizenship" Curriculum 
development of education should concern to

- competence in self-motivation and motivating others; and

- competence in reflection distances on individual models and cultures.

Sustainable development requires social modernization and can only be realized through the active participation of competent citizens; Therefore the concept of "Gestaltungs kompetenz" is characterized in particular with the major competencies necessary for future and autonomous participation in shaping and developing continuing education. Competent education here adapted to the needs in the development of potential areas of course.

\subsection{Human Resource Education Development through Vocational Education}

One of the policies of the Ministry of Education and Culture in developing human resources at Vocatinoal Senior High School introduced in 1993/1994 was the education of Link and Match, meaning that Vocational Senior HIgh School education must be link and match to the needs of students and community to create a suitability between education programs and the needs of community. The link and match policy for vocational secondary education was carried out using Dual System Education program. For vocational education institutions, DSE is neccesary as it influences the graduates to face working world. DSE program is a policy to prepare vocational studentsto be ready and understand the demands of working world.

In contrast to Singapore and Hong Kong State policy efforts, the establishment of an educational center was a natural platform in recruiting foreign workers especially students and researchers. Singapore pursued it more aggressively than Hong Kong because of the implications of declining birth rates and the nearest economic competition (Government of Singapore, 2013). Meanwhile, Hong Kong had China to buffer shortages in urban manpower planning. (Lee, 2014).

\subsection{Public Interest in Vocational Education}

Based on Constitution of the Republic of Indonesia Year 1945, one of the national goals is to educate the life of the nation and to equaly obtain the best education according to one's interests and talents without differentiating in social status, race, ethnicity, religion, and gender. Thus, the learners interest. Interests can be interpreted as the power emerging within the individual to act. Interests greatly affect individual in accepting a certain object and those are influenced by 2 factors, namely:

a. Internal factors, such as:

- Individual talents

- Academic achievement

b. External factors, such as: family socialeconomic condition, including:

- Education background of parents

- Family income and parents' professions

- Number of family

Although attention is directed to the recruitment of international students, developing local talent remains a fundamental goal of educational relationships. Talent development including workforce planning and inclusive provisions that support different interests of local students. On the other hand, the educational relationship does not share the purpose of attracting foreigners and repatriating diaspora talents. Contextual factors such as different political economies and ethnic sensibilities mediate the recruitment of external talents. (Lee, 2014.)

By allowing foreign providers to build campus, host countries are eager to massify higher education, increase research capacity, and enhance the overall excellence of the education system. Importantly, the educational relationship is also interested in developing human talent to compete in the global knowledge economy (Cheng, 2010; Knight and Lee, 2014). Previous studies on educational relationships provide limited analysis of talent development or focuses only on foreign talent (Chan and Ng, 2008; Knight and Morshidi, 2011).

\section{RESEARCH METHODOLOGY}

Explorative study is to examine the relationship amongst the regional potential in order to define the concept of vocational education development in Sumenep. Case study was carried out in conducting this study strated from problems arisen from vocational education development in potential areas in Sumenep.

\subsection{Sampling and Population}

Sampling used in this study was purposive sampling due to (1) background of the respondents (experts) 
very important stakeholders. The analysis of the level of influence of stakeholders are:

limitation of time, cost, and power.

Table 3.2. Score Criteria in Stakeholders Analysis

\begin{tabular}{|c|c|c|}
\hline Score & Level of Influence & Level of Interest \\
\hline 0 & Unknown & Unknown \\
\hline 1 & Low/no influence & Low/unimportant \\
\hline 2 & Low influence & Less important \\
\hline 3 & Influenced & Important \\
\hline 4 & Very influenced & Very important \\
\hline 5 & Highly influenced & Highly important \\
\hline
\end{tabular}

Purposif sampling was conducted by determining certain targets or predefined respondents. These are the sampling according to defined technique, including:

- Education Department of Sumenep

- BAPPEDA Sumenep (Social-Cultural division)

- Scholars

- People who graduated from university or had high intelligence

- Junior High School Students aged $13-15$

- Regional Industry, Trading, and Investment Department

- Community organizations (educational board)

- Trading and Industrial Office Sumenep

- Regional House of Representative of Sumenep (D division of education)

- Education and Culture Department of East Java Province (Vocational Education Division)

\subsection{Data Analysis}

Gradually, the accumulated data was interpreted into the general picture for subsequent analysis according to data allotment in the analysis. This study applied blending qualitative and quantitative technique. Quantitative technique used hierarchical process analysis, while qualitative used Delphi. The analysis steps include:

\subsubsection{Stakeholders Analysis}

Based on paradigm used, ampling was limited to the respondent with specific data and isolated from the environment mentioned using Stakeholders Analysis. Experts in this study were stakeholders or related parties in Vocational Education Development. Each stakeholder has an unequal level of influence and degree of importance. Therefore, to determine the very influential and
- Education Department of Sumenep

- BAPPEDA Sumenep (Cultural division)

- Scholars

- Educational Board

- Regional House of Representatives (Education division)

- Education and Culture Department East Java Province.

\subsubsection{Analysis in determining factors affecting Vocational Education Development to support Regional Potential}

Two types of data were used in this study, primary data obtained by interview, questionnares, as well as surveys, while secondary data derived from existing documentation.

Questionnaire in this article functioned in giving input in determining factors using the Delphi method. Literary study or documentation was to provide complimentary information and data based on existing documents, such as Sumenep in 2016 and Sumenep Potential or data taken from Education Departement and BPS.

This method was to determine alternative programs by exploring assumptions or facts to reach a consensus. The participants are experts in vocational education. Thus, Delphi method employ experts' opinions, experiences and intuitions. These are steps in performing Dhelphi method:

(1) Exploration Phase of Factors Affecting Vocational Education Development as an Effort to Support Regional Potential

Exploration process was conducted by involving the predefined respondents that was by interview and questionnaires describing criteria that affect vocational education development as the results of literature review. Information obtained in prelimanary stage of exploratory process was analyzed until it resulted on factors affecting vocational education development in Sumenep, Madura as follows:

- Population

- Land condition

- Accessibility

- Radius of service (distance)

- Vocational senior high school distribution
- Land use 
comparison with female adolescents? Empirical Res Voc Ed Train (2016) 8:11 DOI 10.1186/s40461-0160037-9

- Government commitment (policy)

- Society participation

- Human resources management of education managers

(2) Iteration Analysis of Factors Affecting Vocational Education Development as an Effort to Support Regional Potential

There are two stages of iteration in Delphi analysis. The first stage is used to obtain the respondent's opinions on the criteria. The second stage is to get similarity of respondent's opinions. The results of the iteration produce criteria affecting vocational education development in Sumenep which was agreed by all respondents. There were several influental factors appeared from the results such as (1) government policy, (2) society participation, and (3) human resources management.

\section{CONCLUSIONS}

Based on the Delphi analysis on iteration, the factors affecting of vocational education development to support regional potential in Sumenep, Madura were: population, radius of service (distance), accessibility, land use, vocational school distribution, natural resource potential, land conditions, society participation, policy-making (government), human resources.

\section{REFERENCES}

Nin O Zarazu' A. M.., 2016. Aid, education policy, and development. Int. J. Educ. Dev.

Alexander Karpov, The Acient Episteme of Activity as Ontological Horison of Modern Education Development. Procedia - Social and Behavior Sciences 214 (2015) 448-456. Peer-review under responsibility of: Bulgarian Comparative Education Society (BCES), Sofia, Bulgaria \& Research International Pusat (IRC) scientific cooperation, Rostov-on-Don, Rusia.

Magnus Fjellström. Vocational learning in a Swedish post- secondary apprenticeship. Empirical Res Voc Ed Train (2017) 9:5 DOI 10.1186/s40461-017-00516

Scholten, Tieben, Vocational qualification as safety-net? Education-to-work transitions of higher education dropouts in Germany. Empirical Res Voc Ed Train (2017) 9:7 DOI 10.1186/s40461-017-0050-7

Beicht and Walden, Transitions into vocational education and training by lower and intermediate secondary school leavers. Can male adolescents compensate for their school- based educational disadvantage in
Andrea Ferraz Young, Adaptation actions for integrated climate risk management into urban planning: a new framework from urban typologies to build resilience capacity in Santos (SP), City, Territory and Architecture An interdisciplinary debate on project perspectives. 2016 3:12

Grill et al. Supervisors and teachers' influence on expectations on empowering leadership among students in vocational education and training. Empirical Res Voc Ed Train (2017) 9:2 DOI 10.1186/s40461-017-0046

Lawale, Bory-Adams. The Decade of Education for Sustainable Development: Towards four pillars of learning Development, 2010, 53(4), (547-550) 2010 Society for International Development 1011-6370/10. www.sidint.org/development/

Setyowati, Wiyono, 2018. Weighting Factors Affecting Vocational Education Development to Support Regional Potential, International Journal of Education and Research 6 (3), 2018.

Wiyono, et al. (2018), Spatial Modeling Vocational Education Development To Support Regional Potential. Ecology, Environment and Conservation. Vol 24, Issue 4, 2018.

Xixi Chen, et al. Landscape Analysis of Geographical Names in Hubei Province, China.entropy ISSN 1099 4300 Entropy 2014, 16, 6313-6337; doi:10.3390/ e16126313. www.mdpi.com/journal/entropy.

\section{ETHICS}

This article is authentic and has unpublished materials. All writers were reviewed and agreed the without any ethics and problems embroiled. 